to the Holy Land and on his way to resume his old chair of anatomy in Padua. There is also a reference to another tragedy, that of Servetus, "who, for a theological quibble, was burned at the stake by order of Calvin and whose books were burned with him"a crime of bad faith that still sends a cold shudder through the sensitive reader.

\section{New World Prehistory}

A PAMPhIET entitled "Cross Sections of New World Prehistory: a Brief Report on the Work of the Institute of Andean Research, 1941-42", by Wm. Duncan Strong, professor of anthropology at Columbia University, has been issued (Smithsonian Misc. Collections, 104, No. 2). The fields covered by the various investigators include eastern and western Mexico, EI Salvador, Venezuela and the West Indies, Colombia, Ecuador, various districts in Peru and the northern coast of Chile. Naturally the information from such a wide area of the Americas that can be given in some 42 pages accompanied by 33 plates is not very extensive; but a general survey like this is of value, and the large relative chronological chart from A.D. 100 to A.D. 1500 will doubtless prove useful to students more interested in the general prehistory of Central and South Ameriea than in its details. There is also a map showing the general location of the excavations undertaken by the Institute.

\section{Remote Switching by Superimposed Currents}

A PAPER was read on this subject in London recently before the Institution of Electrical Engineers by J. L. Carr, in which the author briefly reviewed the methods employed for the centralized control of switching operations on distribution networks, by the injection into the distribution system of currents the frequencies of which differ from that of the main supply. The superimposition of ultra-audio frequencies for limited and specific purposes, such as the protection or the remote switching of a transmission line, has not, so far, been employed to any large extent in Great Britain, and is therefore not considered. Several devices employed to respond to injection currents are briefly described, and the probable applications of this method of control are outlined. Particulars of the development of remote signalling over the network of a large electricity supply undertaking are given, together with reasons for the final adoption of the method selected. Data of the components of the equipment are given, and the power required is analysed for two frequencies.

\section{Recent Earthquakes}

THE United States Coast and Geodetic Survey, in co-operation with Science Service and the Jesuit Seismological Association, has found the epicentres of three recent earthquakes. On January 10 at 20h. $10.0 \mathrm{~m}$. G.M.T., an earthquake had its epicentre in Mexico near lat. $18 \cdot 1^{\circ} \mathrm{N}$., long. $100 \cdot 6^{\circ} \mathrm{W}$. It was recorded throughout America and as far north as Sitka in Alaska. On January 15 at $23 \mathrm{~h} .49 \cdot 4 \mathrm{~m}$. G.M.T., an earthquake had its epicentre in the Argentine near lat. $31 \cdot 5^{\circ} \mathrm{S}$., long. $68^{\circ} \mathrm{W}$. It was recorded throughout America as far north as Alaska and at Honolulu. On February 3 at 12 h. $15 \cdot 2$ m. G.M.T., an earthquake had its epicentre in south-eastern Alaska near lat. $59 \cdot 3^{\circ} \mathrm{N}$., long. $138 \cdot 0^{\circ} \mathrm{W}$. This was recorded by seismographs at Buffalo, Burlington, Chicago, Fordham, Georgetown, Honolulu, Pasadena, Philadelphia, Sitka and Tucson.

\section{Lunar Eclipses and the Earth's Atmosphere}

Sky and Telescope of January 1944 has a short notice with the above title, which describes the photometric results of the lunar eclipse on March 2-3, 1942. These results were obtained in France by Daniel Barbier, Daniel Chalonge and Ernest Vigroux, and indicated, in accordance with the theoretical predictions by Link, a relationship between the intensity of the ozone bands and the distance from the centre of the shadow. Future spectrophotometric studies of lunar eclipses may yield new information on the earth's upper atmosphere.

\section{Physical Society}

AT the annual general meeting of the Physical Society held on May 24 the following were elected or re-elected for 1944-45 : President, Prof. E. N. da C. Andrade; New Vice-President, Sir Edward Appleton; Hon. Secretaries, Mr. J. H. Awbery (Papers) and Dr. W. Jevons (Business); Hon. Treasurer, Dr. C. C. Paterson; New Members of Council, Prof. S. Chapman, Mr. C. H. Collie and Prof. H. R. Robinson. At an extraordinary general meeting held on the same day A. F. Joffe was elected an honorary fellow of the Society. The officers of the Colour Group for 1944-45 are: Chairman, Mr. J. Guild; Hon. Secretary, Dr. W. D. Wright. The officers of the Optical Group for 1944-45 are: Chairman, Prof. A. $O$. Rankine ; Hon. Secretary, Prof. L. C. Martin.

\section{Announcements}

Prof. A. V. HILL, biological secretary of the Royal Society, has been awarded the Joykissen Mookerjee Gold Medal for 1944 of the Indian Association for the Cultivation of Science.

SIR ARdeshir DaLAL, director in charge of the Tata Iron and Steel Co., Ltd., has been appointed a member of the Executive Council of the GovernorGeneral of India, and will be in charge of a newly formed Department of Planning and Development.

Dr. B. A. Keen and Dr. E. B. Worthington, the two British members of the Scientific Advisory Mission to the Middle East Supply Centre, who have been travelling extensively in the Middle East territories for the past seven months, have returned to England for consultations at the Ministry of War Transport in connexion with their draft report and recommendations.

THE American Association for the Advancement of Science will hold its annual meeting for 1944 at Cleveland, Ohio, during September $11-16$. Two previous annual meetings have been cancelled at the request of the U.S. Office of Defense Transportation.

AT the annual general meeting of the Institute of Physics held on May 22 the following were elected to take office on October 1: President, Sir Frank Smith ; Hon. Treasurer, Major C. E. S. Phillips; Hon. Secretary, Prof. J. A. Crowther.

The Summer School in Social Biology arranged by the British Social Hygiene Council to be held in Bangor (see Nature, March 25, p. 373) has been cancelled. 